\title{
青年學生の「文學」に對する態度。の測定
}

\section{COLLEGE STUDENTS' ATTITUDES TOWARDS LITERATURE}

\begin{tabular}{ccc}
\hline 佳 & 野 勝 男* \\
By & SANo, & Katsuo \\
\hline
\end{tabular}

\section{I 問 題}

現代の青年學生は「文學」に對して如何なる態度をも つているが測定せんが爲に，L. L. Thurstone (1)の 等現間隔法 Equal appearing intervals により「交學」 に對する尺度を作り，この尺度を青年學生に施行した。 更にこの結果得られた「交學」に對する態度と兩親の呚 育程度,「スポーツ」に對する態度（2）及び性格の男性 度女性度 (3) との關係をみようとした。

\section{II 測定對象の吟味}

社會的態度を测定せんとする時, 测定の對象が明確な ものであり，自分の態度に郎して制斷してゆく時容易に 賛否を表現し得て，しか子その判斷の過程に於て對象が 他刀類似のものに移行することのないようなものが望ま しい。しかるに「文學」の場合はその意味する所が廣く 且つ漠然としている感をうけるのであるが，調查對象が 青年學生である鹪，大體に於てこの年䶙迄にはいろいろ な交學作品にもら冲る機會も方り，「交學」というもの に略々定まつた概念を持つに至つているのではないかと いらことを豫想した。それ故「交學」を定義づけずに「日 常友達と話し合う時用いる感じ」によつて制斷させるこ とにした。このことは何檢傠を要するものと思われるの であるが，これらを側面的に多少つ檢討を加える篇,「文 學」の範㙹に略々大ると思われるもの九種一即ち(1) 小說 (2)大襄小說 (3)探偵小說 (4) 戲曲 (5)詩 (6)和歌 (7)俳句 (8)隨筆 (9)文藝評論ををげ゙ て自分の最も好むものに○印をつけさせてみた。調查の 對象となつた人員は男子大學矝科生 453 名，女子專門學 校生徒 165 名, 計 618 名である。その結果男女合計の 順位は( 1 位)小說，( 2 位)隨䇤，(3 位)詩，(4 位)探偵 小說, (5 位)文藝評諭, (6 位) 大衆小說, (7 位)俳句, (8.5 位)和歌, 雴曲となつて居り, 男女差は男に於て大衆 小說が 3 位を占めるいるに對して女子に於ては 8.5 位を 占めていることだけである。しかる小說隨筆詩を好む人 が $78 \%$ 占めている。これによれば大體に於て「文學」 と云われた時，小說，隨筆，詩を含むるのを思い出寸る のと考えられたのである。以上により，大體に於て「文 學」には略々定まつた「感じ」があるものと假定し夷の
段階に進しだのである。

\section{III 尺度の作製}

\section{1 意見の菟集及び選擇}

「交學」に對する態度を測定する爲には，先づ態度を 引出すに足る「意見」を集めることが必要である。この 䉆慶大文學部學生 45 名に「文學」に對して思い起寸女 らゆる「意見」を出來るげけ書いて鿓つた。この他文學 量その他からも「意見」を選び出し合馀約 200 の意見を 集めた。これらを先づｉ）「交學」に好意を表わしてい、 る意見 ii) 中立と思わ机る意見 iii）好意を示してい ない意見にに大別し，これらを更に K. A. Wang (4) の發表している規準に照らして意見の選擇を行つた。 K. A. Wang の規準 (criteria) を要約すれば大略次の如き ものである。

i）各種の意見は論氷的ものでなとてはならない。普 遍的㜥理を述べた文章の如きは不適である。

ii）各種の意見は一つの解釋しかないような文章でな ければならない。多義的な解釋を許すような文章は不適 である。

iii）各種の意見は出來るだけ同じ態度の變化を少し づつ示すようなるのでなければならない。

以上の三項目を大略の規濯として約 200 の意見より 53 の意見を選擇した、これら意見を全て記述することは煩 簤であるので，最後迄問題とした 14 の意見のみを表 I に示した。

\section{2 選擇された意見の客觀的評定}

「選擇され九意見」は私個人の主觀によつてなされた ものであるから，更にこれらを教養ある人々に示し，果 してこれら意見が態度を引出すのに適するものであるか どらかを Q 脫逸度によつて檢討し，併せてこれら意見 を尺度上に出來るだけ等間隔に配列せんが瓷に，意見を 別々のカードに印刷し，意見の持つ好意度を 11 段階に 評定せしめた。評定して鿓つた人數は男 28 名女 26 名 計 54 名で何れも皆大學學生又は專門學校生徒である。 これら評定の結果を累加比に直し， $\mathrm{Q}_{2}$ (評定值)，Q 脫 逸度と共に示したのが表 I である。

意見の客蓶的評定の結果を更に檢討与る䉆，男女別に $\mathrm{Q}_{2}$ によつて各意見 53 問を好意度順に並べ，Spearman

*慶應義熟大學心理學研究室 (Department of Psychology, Keiogijuku Uuiversity, Tokyo) 
表 I

意見の $\mathrm{Q}_{2}$ (訶定值)， $\mathrm{Q}$ 踛魀度灸び各評定没階に於ける累加比

\begin{tabular}{|c|c|c|c|c|c|c|c|c|c|c|c|c|c|}
\hline 見（原番號 & I & II & III & IV & $\mathrm{V}$ & $\mathrm{VI}$ & VII & VIII & IX & $\mathrm{X}$ & XI & $\mathrm{Q}_{2}$ & $\mathrm{Q}$ \\
\hline 1 文學は人間最学 & 74 & 8 & 89 & 9 & 94 & 98 & 98 & & 00 & 100 & 10 & .67 & 0.65 \\
\hline 9 交學は如何に生きる心゙きかを敎へる & 35 & 56 & 74 & 89 & 34 & 98 & 100 & & 0 & 0 & 100 &  & 2.26 \\
\hline 2 交學は㗼かな人間性をつくる & 35 & 50 & 85 & 93 & 96 & 100 & 100 & 100 & 100 & 100 & 100 & .00 & 1.95 \\
\hline 13 交攀は自己の見界を & 7 & 3 & 72 & 87 & 96 & 100 & 100 & 100 & 100 & 100 & 100 & 7 & 1.29 \\
\hline 23 交學は互ひに異性の理解を深め & 2 & 1 & 5 & 7 & 96 & 98 & 98 & 100 & 100 & 100 & 100 & 1 & 1.61 \\
\hline 22 交學は讀書のよろこびを與へる & 4 & 15 & 37 & 7 & 98 & 100 & 100 & 100 & 100 & 100 & 100 & 8 & 1.63 \\
\hline 25 交學は人間を善にも惡にも導く影響をもつ & 4 & 6 & 9 & 13 & 2 & 9 & 96 & 98 & 98 & 100 & 100 & 5.41 & 0.73 \\
\hline 34 文學は社會の皇 & 0 & 4 & 7 & 15 & 24 & 54 & 67 & 89 & 96 & 98 & 100 & 5.88 & 2.27 \\
\hline 53 交攀は一つの娛樂て & 2 & 4 & 6 & 13 & 24 & 44 & 69 & 89 & 98 & 100 & 100 & 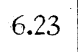 & 2.18 \\
\hline 30 文學は感傷的な人間をつくる & 0 & 2 & 4 & 7 & 20 & 31 & 56 & 85 & 96 & 100 & 100 & 6.77 & 2.13 \\
\hline 42 文學恃性一の好奇心をそ〉る & 0 & 0 & 0 & 2 & 6 & 20 & 48 & 69 & 83 & 89 & 100 & 7.09 & 2.17 \\
\hline $\begin{array}{l}29 \text { 交學は本當に面白くて讀むよりも知的虚策 } \\
\text { のために䜠む傾向をらむ }\end{array}$ & 0 & 0 & 2 & 6 & 7 & 9 & 30 & 48 & 76 & 91 & 100 & 6 & 2.12 \\
\hline 32 文學 & 2 & 2 & 2 & 2 & 4 & 11 & 19 & 37 & 70 & 91 & 100 & & 1.78 \\
\hline 41 交攀は觑策心をそつる原因となる & 0 & 0 & 0 & 2 & 4 & 6 & 9 & 26 & 63 & 85 & 100 & 8.65 & 1.40 \\
\hline
\end{tabular}

の列位差法により男女別の $\rho$ を計算すると $\rho=0.972$ と なつた。こ机によ机ば男の學生は文科系が多く，女の學

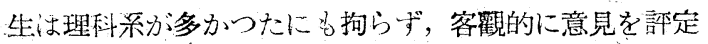

\section{3. 信賴度 $\mathrm{P}$ の決定，類似系數 $\phi$ への換算， $\sigma$ 尺 度へつ換算。}

同一被驗者に二週間の間陻を和いて同じ意見を示しそ の一致度をを調べることにより信賴度を決定しだ。その 式は

$$
P_{1}=\frac{n_{12}}{V n_{1} n_{1}^{\prime}} \text { を用いた }(1)_{0}
$$
したものと思っても差交えないよらに思われる。

$n_{1}$ …意見 1 を最初に被驗者に與えた時の選擇の總數 $n_{1}^{\prime} \cdots$ 意見 1 を二度目に被驗者に與えた時の選擇の總

\section{數}

$n_{12} \cdots \cdots$ 意見 1 を 1,2 包とも選擇した總數

用いた人數は男子學生 (文科, 理科) 259 名, 女子學 生 (文科, 理科) 113 名計 372 名でもる。14 の意見の信 賴度は表 II の同時選擇表に示されている。14の意見の 他, 計算した 50 つ意見の信賴度より一般的に云えば「文 學」光の好意度つ高い意見は信賴度が高いが，好意度の 低い意見は信賴度も低くなつて現われ，選擇される數は 少いが信賴度の高いというものは見られなかつた。それ II

各對の意見に於ける同㫲選擇の頻數

\begin{tabular}{r|r|r|r|r|r|r|r|r|r|r|r|r|r|r|r}
\hline & 1 & 9 & 2 & 13 & 23 & 22 & 25 & 34 & 53 & 30 & 42 & 29 & 32 & 41 & P \\
\hline 1 & 177 & 111 & 145 & 135 & 79 & 113 & 101 & 47 & 37 & 51 & 16 & 34 & 8 & 12 & .67 \\
9 & & 285 & 252 & 243 & 137 & 189 & 178 & 95 & 66 & 83 & 41 & 58 & 17 & 21 & .71 \\
2 & & & 462 & 388 & 168 & 287 & 275 & 137 & 104 & 120 & 58 & 89 & 20 & 29 & .84 \\
13 & & & & 496 & 173 & 288 & 303 & 157 & 118 & 126 & 71 & 105 & 31 & 32 & .87 \\
23 & & & & & 199 & 149 & 143 & 87 & 57 & 62 & 48 & 56 & 19 & 23 & .72 \\
22 & & & & & & 342 & 212 & 120 & 90 & 99 & 57 & 78 & 25 & 20 & .76 \\
25 & & & & & & & 360 & 129 & 101 & 106 & 61 & 97 & 27 & 33 & .78 \\
34 & & & & & & & & 184 & 62 & 68 & 44 & 60 & 11 & 19 & .69 \\
53 & & & & & & & & & 158 & 56 & 36 & 48 & 11 & 22 & .51 \\
30 & & & & & & & & & & 151 & 37 & 44 & 18 & 19 & .65 \\
42 & & & & & & & & & & & 84 & 28 & 10 & 15 & .44 \\
29 & & & & & & & & & & & & 143 & 14 & 28 & .55 \\
32 & & & & & & & & & & & & & 40 & 8 & .40 \\
41 & & & & & & & & & & & & & & 55 & .43 \\
\hline $\mathrm{P}$ & .67 & .71 & .84 & .87 & .72 & .76 & .78 & .69 & .51 & .65 & .44 & .55 & .40 & .43 & \\
\hline
\end{tabular}


表

$\mathrm{Q}, \mathrm{P} ， 及 ひ ゙ \nsubseteq$ 決定に用ひた被驗者數

\begin{tabular}{|c|c|c|c|c|}
\hline \multirow{2}{*}{\multicolumn{2}{|c|}{ 澺見の評定に用ひた人數 }} & \multirow{2}{*}{$\begin{array}{l}\text { 男 } \\
28\end{array}$} & \multirow{2}{*}{$\begin{array}{l}\text { 女 } \\
26\end{array}$} & \multirow{2}{*}{$\frac{\text { 合 計 }}{54}$} \\
\hline & & & & \\
\hline 交 & 信賴度決定つ人數 & 122 & 64 & 186 \\
\hline 科 & $\phi$ 決定の人數 & 277 & 108 & 385 \\
\hline 理 & 信賴度決定の人数 & 137 & 49 & 186 \\
\hline 科 & ф決定の人數 & 176 & 57 & 233 \\
\hline 交 & 信賴度決定の人數 & 259 & 113 & 372 \\
\hline $\begin{array}{l}\text { 合 } \\
\text { 併 }\end{array}$ & $\phi$ 決定の人數 & 453 & 165 & 618 \\
\hline
\end{tabular}

(P 決定の人數と $\phi$ 決定の人數には共通の者が入つて みる)

故尺度を作製するためには，比較的信賴度つ低いものも 探用せざるを得なかつたのである。

次に各意見の心理的類似度を決定せんが鸴に，ある意 見を選摆したものが同時に他つ意見を選擇する頻數を調 べた。表 II にその頻數が示されている。これに用いた 人數は前記信賴度決定に用いた人數に更に男子學生（文 科，理科） 194 名，女子學生 (文科，理科） 52 名計 246 名を追加し, 總計 618 名によつて求めた。今迄 $\mathrm{Q}_{2}, \mathrm{P}$, 及 び同時選擇數を得るために用いた被驗者をまとめて表に

すれば表 III の如くである。

次に表 II の同時選擇數を利用し，各意見間つ類似系 孉市求めた。その式は

$$
\phi_{12}=\frac{n_{12}}{\sqrt{n_{1} r_{2} p_{1} p_{2}}} \text { である(1)。 }
$$

$\dot{\psi}_{12} \quad \cdots$ 意見 1 と 2 の類似系數

$p_{i} \cdots \cdots$ 意見 1 信賴度.

$p_{2} \cdots \cdots$ 意見 2 の信賴度

$n_{1} \cdots \cdots$ 意見 1 を選擇した被羷者の總數

$n_{2} \cdots \cdots$ 意見 2 を選擇した被鐱者つ總數

$n_{12} \cdots$ 意見 1,2 を同時に選擇した被

驗者つ總數

この式によつて計算された類似系數 は表 IVに示されている。この類似系數 фは正常分布をなすおのと假定し，фを $\sigma$ 尺度に换算した。郎ち正常分布曲線の 縱軸を 1 に㧍いた確率表を利用して换算 を行つた(5)。各意見を一對づつ組合わ せたのの分離は表 V に示されている。 この表より計算した尺度值は表 Vの下 欄に示さ札ている。こ扎を圆示すれ代圆 I の如くでむる。以上の手續きによつて 尺度值を決定したのであるが，計算した 尺度つ分離 Calculated scale separation と實羷的尺度の分離 experimental scale separation の食い違い discrepancyは 13\%を示し相當大でまると思われる。こ れは测定對象が比較的莫然としている篇 に生じたものではないかと思われる。

\section{IV 結 果 (1) \\ 一尺度值決当に用ひた dataによる予 備的結是一}

信賴度決定に用いた被驗者（前出表 四）

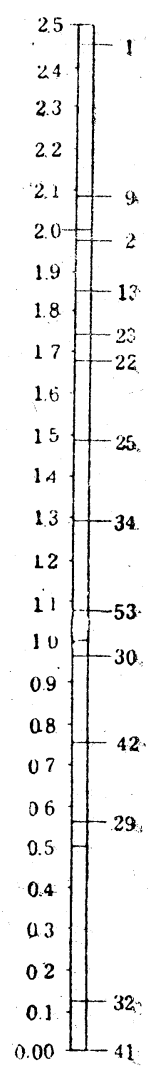

図 I

表 $\quad \mathrm{N}$

各對の意見間の類似系數

\begin{tabular}{|c|c|c|c|c|c|c|c|c|c|c|c|c|c|c|}
\hline & 1 & 9 & 2 & 13 & 23 & 22 & 25 & 34 & 53 & 30 & 42 & 29 & 32 & 41 \\
\hline 1 & 1.00 & .71 & .68 & .59 & .60 & .64 & .55 & .38 & .37 & .47 & .24 & .35 & .18 & .22 \\
\hline 9 & & 1.00 & .89 & .82 & .80 & .82 & .74 & .60 & .51 & .58 & .48 & .46 & .29 & .30 \\
\hline 2 & & & 1.00 & .94 & .71 & .90 & .83 & .61 & .58 & .61 & .48 & .50 & .25 & .30 \\
\hline 13 & & & & 1.00 & .69 & .86 & .87 & .67 & .63 & .61 & .56 & .56 & .37 & .31 \\
\hline 23 & & & & & 1.00 & .77 & .71 & .64 & .53 & .52 & .66 & .52 & .39 & .39 \\
\hline 22 & & & & & & 1.00 & .78 & .66 & .62 & .61 & .58 & .54 & .38 & .25 \\
\hline 25 & & & & & & & 1.00 & .68 & .67 & .61 & .59 & .65 & .40 & .40 \\
\hline 34 & & & & & & & & 1.00 & .61 & .60 & .64 & .60 & .24 & .34 \\
\hline 53 & & & & & & & & & 1.00 & .62 & .65 & .60 & .30 & .50 \\
\hline 30 & & & & & & & & & & 1.00 & .61 & .50 & .45 & .39 \\
\hline 42 & & & & & & & & & & & 1.00 & .51 & .41 & .50 \\
\hline 29 & & & & & & & & & & & & 1.00 & .39 & .64 \\
\hline 32 & & & & & & & & & & & & & 1.00 & .41 \\
\hline 41 & & & & & & & & & & & & & & 1.00 \\
\hline
\end{tabular}


表 $\mathrm{V}$

各對の意見閒の $\sigma$ 分離及び尺度值

\begin{tabular}{r|r|r|r|r|r|r|r|r|r|r|r|r|r|r}
\hline & 1 & 9 & 2 & 13 & 23 & 22 & 25 & 34 & 53 & 30 & 42 & 29 & 32 & 41 \\
\hline 1 & .00 & -.82 & -.87 & -1.02 & -1.00 & -.94 & -1.09 & -1.38 & -1.40 & -1.22 & -1.68 & -1.44 & -1.84 & -1.72 \\
2 & & .00 & -.46 & -.62 & -.66 & -.63 & -.76 & -1.00 & -1.15 & -1.03 & -1.20 & -1.24 & -1.56 & -1.54 \\
13 & & & .00 & -.32 & -.82 & -.45 & -.60 & -.99 & -1.03 & -.99 & -1.20 & -1.17 & -1.65 & -1.54 \\
23 & & & & .00 & -.85 & -.54 & -.52 & -.89 & -.96 & -.99 & -1.07 & -1.07 & -1.40 & -1.52 \\
22 & & & & & .00 & -.72 & -.82 & -.94 & -1.13 & -1.14 & -.91 & -1.13 & -1.36 & -1.36 \\
25 & & & & & & .00 & -.70 & -.91 & -.97 & -.98 & -1.04 & -1.10 & -1.38 & -1.65 \\
34 & & & & & & & .00 & -.87 & -.89 & -.98 & -1.01 & -.93 & -1.35 & -1.34 \\
53 & & & & & & & & .00 & -.99 & -.99 & -.94 & -1.01 & -1.68 & -1.45 \\
30 & & & & & & & & & .00 & -.96 & -.91 & -1.01 & -1.54 & -1.17 \\
42 & & & & & & & & & & .00 & -.99 & -1.18 & -1.26 & -1.36 \\
29 & & & & & & & & & & & .00 & -1.14 & -1.33 & -1.16 \\
32 & & & & & & & & & & & & .00 & -1.36 & -.93 \\
41 & & & & & & & & & & & & & .00 & -1.33 \\
$\Sigma$ & 16.42 & 11.04 & 9.42 & 7.85 & 6.18 & 5.45 & 2.88 & 0.08 & -2.93 & -4.49 & -7.32 & -10.13 & -1638 & -18.07 \\
\hline 差 & 5.38 & 1.62 & 1.57 & 1.67 & 0.73 & 2.57 & 2.80 & 3.01 & 1.56 & 283 & 2.81 & 6.25 & 1.69
\end{tabular}

\begin{tabular}{l|lllllllllllllll} 
差 $\mathrm{N}$ & 0.3843 & 0.1157 & 0.1121 & 0.1264 & 0.0521 & 0.1836 & 0.200 & 0.2150 & 0.1114 & 0.2022 & 0.2007 & 0.4464 & 01207
\end{tabular}

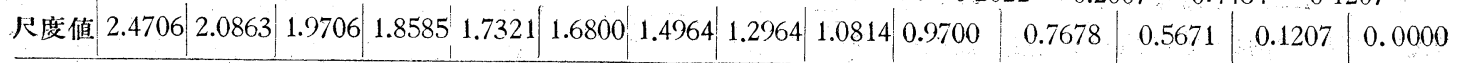

即ち交科系（鹿大經濟學部豫科一年) 122 名，理科系(鹿 大醫學部工學部豫科一年) 137 名，女子の方は日本女子 大一年 64 名，東京女子醫專一年 49 名刃「文學」に對 する態度の點は表 VI の如くである。尺度の點は 100 倍 したものを用いた。

$$
\text { 表 VI }
$$

信賴度決定に用ひた被驗者郡の本均尺度值

\begin{tabular}{l|r|r||r|r}
\hline & 慶大經游 & 慶大醫工 & 日本女子大 東京女子醫 \\
\hline M & 155.86 & 165.09 & 168.09 & 167.80 \\
$\sigma$ & 24.81 & 29.70 & 26.12 & 24.36 \\
\hline
\end{tabular}

表 VI によると日本女子大が一番「文學」に對する態 度は高く, 次いで東京女子醫，慶大醫工，慶大經濟の順 であるが，經濟學部を除いては他の差はあまり顯著では ない。のが大なるのをみれば大體に於て等しいと認め て差支へない程度ではないかと思われる。

次いで類似系數 $\phi$ 決定に用いた被驗者（前出表 III） 郎ち經濟學部 277 名, 醫工學部 176 名, 日本女子大 108 名，女子醫 57 名を「文學」に對する一般的態度によつ て分類してみた。「文學」に對する一般的態度は次の五 段階でする。

I 文學は大好きです

II 攻學は好きな方です

III 交學は好きでも蛪いでもなく中位です。

IV 交學は嫌いな方です

$\mathrm{V}$ 文學は大嫌いです。

この五つの段階を示し，自己が「文學」に對して持う
ている態度に一致する項に○をつけさせ，それと態度の 得點との關倸を調べたのである。表 VII かその結果で ある。これによると經濟學部，醫工學部，日本女子大に

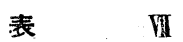

「交學」に對する一般的態度と尺度による㦔度得點と の關係

\begin{tabular}{|c|c|c|c|c|c|c|c|c|}
\hline & \multicolumn{2}{|c|}{ 經 濟 } & \multicolumn{2}{|c|}{ 醫 I } & \multicolumn{2}{|c|}{$\begin{array}{l}\text { 日本女子 } \\
\text { 大 }\end{array}$} & \multicolumn{2}{|c|}{ 女子䇴 } \\
\hline & M & 人數 & $\mathrm{M}$ & 人 & M & 數 & M & 人 \\
\hline $\begin{array}{l}\text { I交學は大好 } \\
\text { きです }\end{array}$ & 154.65 & 45 & 169.67 & 726 & 164.22 & 30 & 175.28 & 16 \\
\hline II 交學は好き & 159.04 & 145 & 173.58 & 875 & 169.04 & 451 & 164.88 & 30 \\
\hline $\begin{array}{l}\text { 文學は好き } \\
\text { 而も゙婙ひで } \\
\text { むなく中位 } \\
\text { です }\end{array}$ & 150.61 & 80 & 156.17 & 763 & 152.87 & 721 & 154.00 & 10 \\
\hline 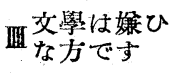 & 141.21 & 5 & 172.76 & 610 & 169.29 & 6 & 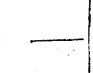 & 0 \\
\hline $\mathrm{V}$ 交學は大婙 & 54.78 & 1 & 22.92 & 21 & . & 0 & 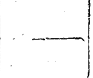 & 0 \\
\hline
\end{tabular}

於ては II 文學は好きな方ですの點が一番高く，女子婜 のみが I 文學は大好きです の點が一番高い。I,II, III に品等した人々の態度の點は一般に大差なく，それらを 辩別する力はこの尺度には見られないように思われる。 IV，V に品等した人々の態度の點は二つの例外を除いて は低く，「交學に好意をもつ人と「文學」は嬮いだとい。 ラ人の間に於ける差は辫別しうるのではないかと考兄ら れる。 


\section{$\nabla$ 結 果 (2)}

IVに於て豫備的檢討をなした後，「交學」に對する尺 度の他, 兩親の教育程度 ( 1 大學高專卒 - 2 中等學校卒 3 小學校卒)，古賀行義敉曖の作製した「スポーッ」に 對する態度測定の尺度及び日本大學作製の男性度女性度 撿查法を作用し，それらとの關係をみようとした。用い な被驗者は表 VIII の如くである。

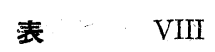

結果 $(\boldsymbol{Z})$ に於て用いた被殮者

\begin{tabular}{|c|c|c|c|}
\hline & 2 年 & 3 年 & 計 \\
\hline 經濟學部予科 & - & 114 & 114 \\
\hline 法學部予科 & 25 & 31 & 56 \\
\hline 交學部予科 & 31 & 26 & 57 \\
\hline & & & 227 \\
\hline
\end{tabular}

「交學」と「スポーツ」の態度の點及び兩者の相關を とれば表 IX の如くになる。㻏工，女子醫は尺度值決定 の特の dataを用いた。

\section{表 $\quad$ IX}

「交學」と「スポーツ」との r 及び「交學」「スポーツ」 の M 及び $\sigma$

\begin{tabular}{|c|c|c|c|c|}
\hline & $\mid \begin{array}{l}\text { 交学とスポ } \\
\text { ーツの }\end{array}$ & 交緮の M $\sigma$ & $\begin{array}{l}\text { スポ-・ } \\
\infty \mathrm{M}\end{array}$ & $\sigma$ \\
\hline 文經法 222 名 & 0.206 & $169.85 \quad 27.90$ & 131.51 & 20.21 \\
\hline 醫 工 158 名 & 0.467 & $168.05 \quad 29.70$ & 135.89 & 11.85 \\
\hline 女子醫 49 名 & 0.039 & $167.83 \quad 24.36$ & 144.53 & 5.65 \\
\hline
\end{tabular}

㗨工學部が一番相關が高く，文經法，女子醫となつて いる。文經法に於ける $\mathrm{r}=0.206$ は歸無假設を $\rho=0$ と 抬いて檢定したが， $\rho=0$ とは認められないことを示し た。

次いで「文學」と「男性度女性度檢查」との $\mathrm{r}$ をとれ ば（交經法 222 名） $\mathrm{r}=-0.032$ となり，「スポーツ」と 「男性度女性度檢查」との r をとれば（交經法 210名） $\mathrm{r}=-0.043$ となつた。男性度女性度檢查法は 5 項目に分 れている。郎ち

1 項 怒りの situation を與えて区應をきく

2 項 恐怖の situation を與えて反應をきく

3 項 嫌惡の situation を與えて反應をきく

4 項 同情の situation を與えて反應をきく

5 項 邪惡の situation を與えて反應をきく

以上の各項と「文學」「「スポーッ」との $\mathrm{r}$ をとれ゙ 表 X の如くである。

\section{表 $\mathrm{X}$}

「文學」「スポーツ」と男性度女性度检查の各項と 0 r (交經法 221 名)

\begin{tabular}{|c|c|c|c|c|c|}
\hline & I 恐 y & II 恐怖 & 媖惡 & IV同情 & $\mathrm{V}$ 邪輜 \\
\hline 交 學 & 0.036 & 0.042 & -0.445 & -0.128 & -0.063 \\
\hline スポーツ & -0.011 & 0.053 & -0.253 & -0.111 & -0.090 \\
\hline
\end{tabular}

III 骕㷂を示寸項の $\mathrm{r}$ が「文學」との場合少し高いの を除いては他は 0 は近いるのとみて差支えないと思的 る。

次に兩親の敉育程度 ( 1 大學高專卒 2 中等學校卒 3 小 學校卒）によつて「交學」の態度をみたのであるが，殆 ど點つ動きは認められなかつた。「スポーッ」に對する 態度も「男性度女性度檢查」の結果も同樣に分類してみ たが，殆ど差は認められなかつた。

\section{II 要 約}

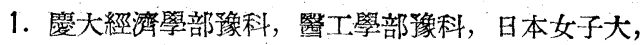
東京女子醫專の間に於ては「交學」に對する態度は殆ど 差が認められなかつた。女子の方が少しく高いようにも 思われるがのが大である䉆に有意には思われない。こ れが尺度の俁差からくるものであるか，本來的にそうで あるかは今後の检討を要する。

2.「交學」に對する一般的態度を辫別しらる力をこ の尺度は持つていないように思われる。但し「交學は大 好きです」と「交學は好きな方です」を一まとめにし， 「交學は好きでも嫌いでもなく中位です」より以下 IV Vの一般的態度を一まとめにすれば，その差は略々辨別 しらるよらに思われる。

3.「交學」に對する態度と「スポーッ」に對する態 度の相閐は文經法 0.206 , 繁工 0.467 ，女子醫 0.039 で あり，一般に低い。

4.「文學」に對する態度と「男性度女性度檢查法」 との相關は -0.032 であり，「スポーッ」に對する態度 と「男性度女性度檢查法」との相關は - 0.043 であり， 殆ど相闠はないものと思われる。

5. 「男性度女性度檢查法」の各 sub-test との相關 は「交學」に對する態度と III（嫌惡をきく問題）の間 にー0.445の反對關係が少しくみられ，「スポーッ」に 對する態度と III との相關 -0.253 が認められる以外は 殆ど 0 に等しい。

6. 兩親つ敉育程度によつて「文學」「スポーッ」「男 性度女性度檢查法」の點には殆ど差は認められないよ゙ に思われる。

以上が大略の暫定的結果でもるが，態度測定には對象 の選擇と意見の作製が非常な影響を及ぼすように思われ る。この點は慣重に考慮されるべきであると感じた。

\section{ABSTRACT}

In this study, the attitudes of college students towards literature were measured by a scale constru 
cted after the manner of Thurstone's attitude scale( 1 ) and compared with their attitudes towards sports as measured by Prof. Koga's scale (2) and with their emotional responses as tested by Terman's $M-F$ Test, Part $111(3)$. An attempt was made also to see if there were any relation between the re ults of these tests and the educational grades of the parents of the $t$ stees.

Constructi $n$ of the scale $\cdots$... Out of about 200 opinions on literature col'ected by the writer, 53 were selected on the basis of K. A. Wang's criteria. These were rated by 54 judges and three of them were omitted on account of their high $\mathrm{Q}$ values. To test the reliability, the remaining 50 statements were then given to 372 students who gave ratings twice at an interval of two weeks. The statements finally adopted and their scale values folow:

No. Statements Scale values

1. Literature is the highest art of mankind.....

2. L. teaches us how to live. 2.0863

3. L. cultivates a sympathetic attitude towards life.

4. L. gives us a wicker view of life. 1.8585

5. L. promotes the mutual understanding betwe en men and women. 1.7321

6. L. gives us the pleasure of reading. …. 1.6800

7. L. has both good and bad effects upon us. 1.4964

8. L. exposes the dark side of life. ...........1.2964

9. L. is an amusement and nothing more. $\cdots 1.0814$

10. L. makes man sentimental. ............... 0.9700

11. L. excites our curiosity about the opposite sex. 0.7678

12. L. is read by those who want to satisfy their vanity rather than by those who seek genuine pleasure.

13. L. deprives us of scientific spirit.

14. L. is apt to make man vainglorious, $\cdots . .0000$

Discreparcies between the experimental scale separation and the calculated scale separation were 13 $\%$ of the total range of scale values. This was perhaps due to the ambiguity of the meaning of literature.

Results .... The scale was given to three groups of students: the students of 1) Department of Literature, of Economics and of Law, 2) Lepartment of
Medicine and of Engineering, of Keiogijuku University and 3) Tokyo Girls' Medical College. The total number of subjects was 794 . The results may be summarized as follows :

1. With respect to the attitude towards literature, there was practic lly no diffe ence among the different groups of students. The female students showed a little more preference towards literature than the male stucents, however, the difference was found to be statistically insiginificant.

2. The scale used seemd to be inadequate to discriminate between the five general attitudes towards literature as expressed in the following statements: (1) I decidedly like literature, (2) I rather like literature, (3) I neither like nor dislike literature, (4) I rather dislike literature and (5) I decidedly dislike literature. However, it may discriminate 1) and 2) from the remaining three attitudes, 3) 4) 5).

3. The coefficients of correlation between the attitudes towards literature and sports were:

(a) Dept. of Literature, Economics \& Law $\cdots 0.206$

(b) Dept. of Medicine \&Engineering …........ 0.467

(c) Girls' Medical College 0.039

Application of null hypothesis $(\rho=0)$ to (a) showed that the correlation was significant at its value.

4. The coefficient of correlation betwe $=n$ the atta itudes towards literature and the results of the emotional response test was -0.032 and that between the attitudes sports and emotional responses was -0.043 .

5. The educat onal grades of the parents of the testees had no influence upon the results the various tests given in this study.

\section{文献}

1. L. L. Thurstone, Theory of attitude measure mont. Psyclio!. R.v.1929, 36, 222-241.

2. 古賀行義「競技に對する態度の測定」心理學呼焱 第九卷，五・六輯，211-235.

3. 日本大學作製「簡易性度檢查法」

4. K. A. Wang Suggested criteria for writi g at:itude statements. J. So:. Psy.hol., 1932, 3, 367-373. （紹介：波多野完治「現代心理學說研究」上赏 220-224)

5. O. H. Rugg, Statistical methods applied to édu. cation. Appendix, Table II, 388, 1917.

(1949 年9月 15 日原稿受付) 